\title{
Analysis Of Taxpayer Annual Reporting Of Taxpayer Manually To The Tax Revenue Target In Buleleng Regency
}

\author{
I Gusti Ayu Purnamawati ${ }^{1}$, Dwi Arini Nursansiwi ${ }^{2}$ \\ ${ }^{1}$ Faculty of Economics, Universitas Pendidikan Ganesha \\ 2 State Administration, Sekolah Tinggi Ilmu Politik Mbojo
}

A R T I C L E I N F O

Article history:

Received 26

Desember 2017

Received in revised form

8 Januari 2018

Accepted 12

Februari 2018

Available online 25

Februari 2018

Kata Kunci:

Pajak, Pengembalian

Pajak Tahunan,

Target Penerimaan.

Keywords:

Taxes, Annual Tax

Returns, Acceptance

Targets.

\section{A B S T R A K}

Penelitian ini bertujuan untuk mengetahui analisis wajib pajak pelaporan wajib pajak tahunan secara manual terhadap target penerimaan pajak di Kabupaten Buleleng pada tahun 2015. Data yang digunakan adalah data kualitatif berupa jumlah wajib pajak wajib SPT dan realisasi pengembalian pajak. Teknik pengumpulan data yang digunakan adalah metode wawancara dan dokumentasi yang dianalisis dengan menggunakan analisis deskriptif kualitatif. Hasil penelitian menunjukkan: jumlah target pelaporan SPT tahunan dengan realisasi penerimaan SPT tahunan telah melampaui target sehingga dapat dikatakan telah tercapai. Faktor-faktor yang mempengaruhi pencapaian target penerimaan pajak di Kabupaten Buleleng tahun 2015 adalah kepatuhan wajib pajak dalam melakukan pelaporan SPT tahunan.

A B S T R A C T

This study aims to determine the analysis of taxpayer annual reporting of taxpayer manually to the target of tax revenue in Buleleng regency in 2015. The data used are qualitative data in the form of the number of mandatory taxpayers required SPT and the realization of tax returns. Data collection techniques used are interview and documentation method which is analyzed by using qualitative descriptive analysis. The results showed: the number of annual SPT reporting targets with the realization of annual SPT receipts has exceeded the target so that it can be said has been achieved. Factors that influence the achievement of tax revenue target in Buleleng Regency in 2015 is taxpayer compliance in conducting annual SPT reporting. 


\section{Introduction}

Taxes are a compulsory State duty owed by those obliged to pay them according to regulations with no immediate reinstatement, which is directly appointed, and the point is to finance general expenses relating to the task of the State administering the government. (Andriani in Waluyo, 2011: 2). To optimize the tax revenue as a source of state revenue, tax reform needs to be done from time to time with a fixed based on social justice. One type of tax is income tax. Income Tax imposed on the Tax Subject of income received or accrued in the tax year. The tax subject is taxed upon receipt or income. Tax receipts may be interpreted as revenue derived from the sale of goods and services produced by the government, which is a tax imposed on the imposition, may be levied periodically repeated within a certain period of time both tax and tax year. From the above definition, any individual who carries on business or an individual who carries on his or her own business in any form shall be subject to tax under section 25.

Such optimization is intended to generate tax revenue and also consider justice in treating taxpayers. Therefore, efforts are made to each taxpayer will get a turn to be examined in order to test the fulfillment of tax obligations (Syahab and Gisijanto, 2008: 3). Individual Tax Payer stipulated in Law No. 7 of 1983 on Income Tax as already amended several times last by Law Number 36 of 2008 Article 25 Paragraph (7). And Implementation of Income Tax Imposition Article 25 For individual taxpayer own business is set in Regulation of Director General of Tax Number PER-32 / PJ / 2010. One type of tax is Income Tax also has many types one of which is the Personal Income Tax that uses the form 1770 as Notice (SPT) is one income tax that contribute greatly to the state income. With various efforts that make various renewal in the field of taxation, including in raising awareness of Individual Taxpayers who use the form 1770 will perform the obligation of reporting in accordance with applicable provisions.

Form 1770 for reporting must be correct, clear and complete with attachments that must be conveyed in accordance with the time limit specified. Where reporting is by using the form 1770 personally manually for Income Tax 25 which is an Income Tax installment that must be paid by the taxpayer every month and reported every year. Based on the annual SPT reporting during 2015 in general based on data obtained from KPP Pratama Singaraja for 2015 non-employee personal taxpayers or registered private business as many as 14,423 , for registered taxpayers mandatory SPT personal nonemployees or own business as much as 5.692, for SPT reporting targets of non-employee personal or selfemployment as much as 2,561 while for the realization of receipt of annual taxpayer annual taxpayer personal non employees or own business in the year 2015 as much as 2571. Considering that KPP Pratama Singaraja conducts annual SPT reporting with 1770 forms manually required from 2008, and it is also necessary to know whether or not the target of tax revenue in KPP Pratama Singaraja with manual form 1770 is made. So that tax revenue in KPP Pratama Singaraja 2015 in say reached because exceed the target set from the center.

\section{Methods}

In the research design the first thing to do is to determine the location of research where the authors conducted research on KPP Pratama Singaraja which is located at Jalan Udayana No 10 Singaraja, Buleleng District, Buleleng Regency. After the location of research has been determined then the researchers see the phenomenon or things like what happened in KPP Pratama Singaraja. Then from the phenomenon can be made formulation of the problem. The study of the theory was made after the formulation of the problem, it is intended to know what materials can be used for this research. From the study of this theory, researchers can determine what data are needed to research. The data used in this study are qualitative data in the form of description of the number of registered taxpayers, the number of mandatory taxpayers SPT, the number of reporting targets, the amount of realization of tax returns. The data that have been obtained is then processed and analyzed using qualitative data. From the data processing the authors get the results of research, from the results of this study will be concluded whether the tax revenue in KPP Pratama Singaraja achieved or not achieved.

\section{Results and Discussion}

The tax payers in KPP Pratama Singaraja for 2015 for the number of non-employee registered taxpayers totaling 14,4213 , and for registered taxpayers, the SPT for registered non-employee personal is 5,692 , for the target of SPT report of non-employee personal is 2,561 and for the realization of receipt of non-employee personal tax return of 2,571. Advantages and Disadvantages of Annual Report of Taxpayer's Annual Tax Return with Form 1770 Manually. So the advantages and disadvantages of taxpayer annual reporting of SPT with 1770 form manually on KPP Pratama Singaraja are as follows: 1) 
Excess annual reporting of SPT with Form 1770 manually a) In the form there is a complete additional information such as: list of assets, list of payables / obligations, family members composition, monthly installment recaps, and monthly final tax recap. b) In the reporting of SPT can be done or reported to come to KPP Pratama Singaraja directly and fill the form 1770 directly. c) Reporting can be done anytime during office hours. 2) Lack of reporting of SPT Annual with Form 1770 manually a) Manual reporting should come to the office directly because the manual system is not online. b) Must come to the office to fill in the form form at least if not know at all about the filling can ask Account Representative which is a liaison partner between the DGT with the taxpayer

\section{Conclusions and Reccomendations}

From research that researchers do in KPP Pratama Singaraja to get taxpayer data with documentation for analysis of taxpayer annual reporting of taxpayer with form 1770 manually to the target of tax revenue in 2015. From table 4.1 above can be seen that for tax recipients in KPP Pratama Singaraja for year 2015 for the total number of non-employee registered taxpayers of 14,4213 registered taxpayers and registered taxpayers of SPT for registered personal non-employee of 5,692 for nonemployee personal reporting target of 2,561 and for the realization of non-employee income tax return as many as 2,571 . Based on the results above, it shows that tax receipts for non-employee private persons for 2015 are said to reach the defined revenue target. In 2015, the registered taxpayers are obliged to SPT for non-employee personal as much as 5.692 with the percentage of $39 \%$ in the can from the taxpayer (registered taxpayer is non-employee personal taxpayer: taxpayer registered person non employees $\mathrm{x}$ $100 \%$ ), for SPT reporting targets non personnel employee 2,561 with a percentage of $45 \%$ which this percentage is an absolute number requested by the head office against the SPT reporting targets while for the realization of receipt of non-employee personal SPT as much as 2571 with $100 \%$ percentage which where obtained from (realization of taxpayers people personal non employee: SPT non-employee personal reporting target x 100\%). So if seen from the number of SPT reporting targets that have been determined by the head office on the realization of receipt of non-employee personal tax returns in the KPP Pratama 2015 in say optimal or achieved.

Analysis of taxpayer annual reporting of taxpayer form 1770 manually to tax revenue target in KPP Pratama Singaraja year 2015 is if reporting of annual tax return of individual taxpayer have fulfilled target specified then target of tax revenue at KPP Pratama Singaraja said reached. Tax revenue is said to be optimal or achieved because the bottom line is the number of targets requested by the head office as much as 2561 with the percentage of $45 \%$ which has been determined from the head office with the realization of receipt of SPT as much as 2571 with $100 \%$ percentage that has exceeded the target number. Based on the targeted reporting targets for KPP Pratama Singaraja with the realization of tax revenues in KPP Pratama Singaraja can be seen that the tax revenue in for 2015 in KPP Pratama Singaraja said reached.

Factors influencing the achievement of annual SPT reporting with manual form 1770 against tax revenue targets are taxpayer compliance in reporting SPT, socialization of tax officials and electronic media assisting in notification for annual SPT reporting such as: radio, newspaper, billboards , tv ads and so forth.

\section{Reference}

Buku panduan hak dan kewajiban wajib pajak. Di unduh dari http://www.pajak.go.id/sites/default/files/HKWP-Bab2 0.pdf di akses pada tanggal 3 April 2017

Dierektorat Jenderal Pajak. 2017 tersedia pada https://www.online-pajak.com/id/spt-suratpemberitahuan Di akses pada tanggal 2 April 2017

Safri Nurmantu. 2005.Pengantar tersedia pada http://books.google.co.id. Di akses tanggal 27 maret 2017

Santoso Broto Diharjo. 1991. Pengantar Ilmu Hukum Pajak. Edisi Revisi. Bandung: Erosco

Waluyo. 2010. Pengertian Pajak tersedia pada http://www.artikelsiana.com/2015/02/pengertian-pajakdefinisi-para-ahli-pajak.html di akses tanggal 2 April 2017. 